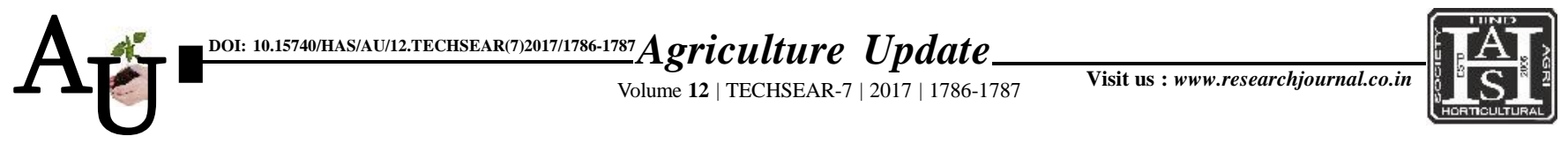

\title{
Research Article: Effect of planting geometry on cane yield and water productivity under sub-surface drip fertigation system
}

Article Chronicle : Received : 19.07.2017;

Accepted : 03.08.2017

KeY Words:

Sub surface, Planting geometry, Yield, Yield attributes, Sugarcane

\section{VIJAYAKUMAR, M. MOHAMED YASSIN, A. SUDHA AND M. SENTHIL KUMAR}

SUMMARY : Field experiments were conducted at Agricultural Research Station, Bhavanisagar, Tamil Nadu from 2008 to 2011 to optimize the row spacing and planting geometry under sub-surface drip fertigation system. The experiment was laid out in a Randomized Block Design and replicated thrice. The treatments imposed were Lateral spacing of $120 \mathrm{~cm}, 135 \mathrm{~cm}, 150 \mathrm{~cm}, 165 \mathrm{~cm}$ and $180 \mathrm{~cm}$ of either single row or dual row planting.The result indicated that among the different crop geometry lateral spacing of $180 \mathrm{~cm}$ planted in dual row recorded significantly the higher cane yield $\left(165.2 \mathrm{t} \mathrm{ha}^{-1}\right)$ and was comparable with both single and double row planting of 150 lateral spacing than the lateral spacing of $120 \mathrm{~cm}$ planted in single row $\left(101.6 \mathrm{t} \mathrm{ha}^{-1}\right)$.

How to cite this article : Vijayakumar, M., Yassin, M. Mohamed, Sudha, A. and Kumar, M. Senthil (2017). Effect of planting geometry on cane yield and water productivity under sub-surface drip fertigation system. Agric. Update, 12(TECHSEAR-7) : 1786-1787; DOI: 10.15740/HAS/AU/12.TECHSEAR(7)2017/1786-1787.
Author for correspondence :

\section{VIJAYAKUMAR}

Krishi Vigyan Kendra (TNAU), SALEM (T.N.) INDIA

Email : mvijayakumar75 @gmail.com

See end of the article for authors' affiliations 